\title{
Estimating the mass balance of Vatnajökull, Iceland, from NOAA AVHRR imagery
}

\author{
G.H.K. CALLUY, ${ }^{1}$ H. BJÖRNSSON, ${ }^{2}$ J.W. GREUELL, ${ }^{1}$ J. OERLEMANS ${ }^{1}$ \\ ${ }^{1}$ Institute for Marine and Atmospheric Research, Utrecht University, 3508 TA Utrecht, The Netherlands \\ E-mail: G.H.K.Calluy@phys.uu.nl \\ ${ }^{2}$ Science Institute, University of Iceland, Dunhaga 3, IS-107 Reykjavík, Iceland
}

\begin{abstract}
We investigate the possibility of obtaining the mass balance of Vatnajökull, Iceland, from US National Oceanic and Atmospheric Administration (NOAA) Advanced Very High Resolution Radiometer (AVHRR) albedo images for the years 1991-2002. De Ruyter de Wildt and others (2002) demonstrated that the mean potential absorbed radiation $\left(\left\langle Q_{\text {pot,net }}\right\rangle\right)$ averaged over the melting season correlates well with the mean specific mass balance and that $\left\langle Q_{\text {potnet }}\right\rangle$ can be estimated from the evolution of the surface albedo. Here, we improve the retrieval method of de Ruyter de Wildt and others (2002) by introducing the more realistic $6 \mathrm{~S}$ atmospheric transfer model and by adding the latest narrowto-broadband (NTB) albedo conversion equations. Bidirectional reflectance distribution functions for both ice and snow are used where appropriate. We show that the choice of the NTB conversion equations greatly influences the calculated $\left\langle Q_{\text {pot,net }}\right\rangle$. Measured mass balance correlates well with $\left\langle Q_{\text {pot,net }}\right\rangle$ if enough cloud-free images can be found through the year and if the spatial variation in measured mass balances is high enough. The correlation coefficient for all drainage basins combined is 0.92 , with a residual standard deviation of $0.18 \mathrm{~m}$ w.e. We present an estimated mass-balance series for the whole of Vatnajökull based on our findings. Switching between different AVHRR instruments over time may cause serious errors in the calculated mass balance.
\end{abstract}

\section{INTRODUCTION}

Compared with traditional approaches, satellites enable us to observe more glaciers, especially those that are difficult to reach, more frequently. Different remote-sensing methods can be used to measure glacier extent, height, velocity and surface mass balance (Konig and others, 2001; de Ruyter de Wildt and others, 2002).

In this paper, we discuss surface mass balance. Traditional approaches require many stakes to obtain a good spatial distribution of accumulation and melt (Pelto, 2000). Satellites, however, have the potential to deliver mass balance at a higher spatial resolution because they can be used to provide representative images of surface albedo (Reijmer and others, 1999). How mass balance and surface albedo are related is discussed below.

Before mass balance can be inferred purely from satellite images, the procedures need to be tested thoroughly. Many authors have already worked on this subject. Some have tried to relate the position of the snow-line at the end of the ablation season to the mass balance because the snow-line is a surrogate for the equilibrium line, which can be used to infer the mass balance. For example, Hall and others (2000) and de Ruyter de Wildt and Oerlemans (2003) used synthetic aperture radar (SAR) to look at the snow-line and equilibrium-line positions in Iceland. They found that the equilibrium line could be obscured by the firn line of the previous year if that firn line lies below the snow-line. Hall and others (2000) also argued that Landsat images were preferable to SAR images, because they better distinguish the glacier from the surrounding moraine. Another disadvantage of the SAR method is that it requires a good image at a specific moment, something that can be quite difficult in Iceland because of its frequent cloudiness.
An alternative method to using the satellite-derived snowline position is to use satellite-derived surface albedo or potential absorbed radiation at the surface, which is derived from albedo. Among the first authors to use Advanced Very High Resolution Radiometer (AVHRR) images to derive the albedo of a glacier were Koelemeijer and others (1993). Subsequent authors improved the technique by correcting for surface slope (Knap and others, 1999; de Ruyter de Wildt and others, 2002). Recent papers have improved the technique further by adding an atmospheric correction, and a correction for the anisotropic reflection of radiation by either ice (Stroeve and others, 1997) or snow (de Ruyter de Wildt and others 2002) or both (Klok and others, 2003).

In this paper, we present a dataset of calculated radiation from 1991 to 2002, which we compare with in situ measurements of surface mass balance. The images are from Vatnajökull, Iceland (Fig. 1), one of the largest ice caps in Europe. They were taken by the AVHRR instruments aboard US National Oceanic and Atmospheric Administration (NOAA) satellites, specifically NOAA-11, NOAA-14 and NOAA-16. The AVHRR instrument has a rather coarse resolution ( $1.1 \mathrm{~km}$ at nadir) compared to some other satellite instruments (e.g. those on the Landsat satellites $(30 \mathrm{~m}$ at nadir)), but it is adequate for an ice cap as large as Vatnajökull $\left(8300 \mathrm{~km}^{2}\right)$. An advantage of AVHRR is that the satellite passes over the area several times a day. A negative aspect of Vatnajökull is that it lies in an active volcanic area, so its surface can be affected by factors unrelated to incoming radiation, like volcanic ash, which can change the albedo.

Images from 1991 to 1999 have already been presented by de Ruyter De Wildt and others (2002). Because many steps in the procedure have been changed in our study, these images were reprocessed to produce a homogeneous AVHRR radiance time series. The method described below requires 


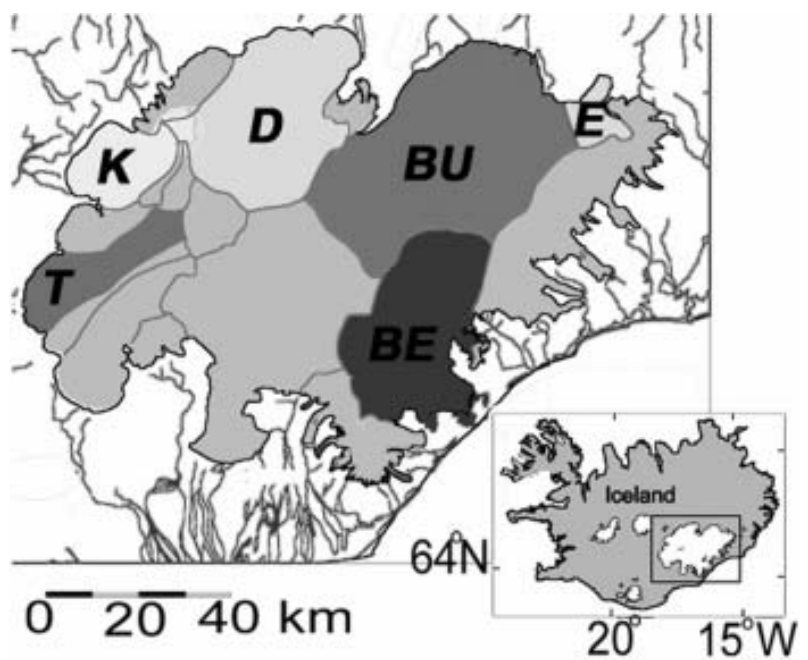

Fig. 1. Location of Iceland (inset) and Vatnajökull. Several drainage basins are marked: T, Tungnaarjökull; K, Köldukvíslarjökull; D, Dyngjujökull; BU, Brúarjökull; BE, Breiáamerkurjökull; E, Eyjabakkajökull.

visual inspection of images at several steps, especially for the detection of clouds, but it is computationally efficient.

\section{ALBEDO AND MASS BALANCE}

De Ruyter De Wildt and others (2002) showed that the mean surface mass balance $(b)$ correlates well with the potential absorbed radiation $\left(Q_{\text {pot, net }}\right)$ averaged over a glacier surface over the melt season, and to a lesser extent with the average surface albedo $(\alpha)$. This is because the amount of shortwave radiation absorbed by the surface greatly influences the amount of summer melting. The winter balance is also taken into account by this method: if more snow has fallen, it will take longer to melt and the surface albedo will remain high for a longer period. To some extent, this method is sensitive to summer snow, which can have a great effect on albedo for a few days, while not being very important for the overall mass balance (Greuell and Oerlemans, 1986).

Net potential radiation is defined as

$$
Q_{\text {pot, net }}=Q_{\text {pot }}(1-\alpha) \text {. }
$$

$Q_{\text {pot }}$ is the amount of radiation that would reach the surface if the atmosphere were completely transparent. It can be calculated from standard astronomical theory (Walraven, 1978). The mass balance $(B)$ is related to the summer $Q_{\text {pot,net }}$ averaged over the whole ice cap $\left(\left\langle Q_{\text {pot, net }}\right\rangle\right)$ :

$$
B \sim \frac{1}{D} \int_{\text {Summer }}\left\langle Q_{\text {pot, net }}\right\rangle \mathrm{d} t \text {, }
$$

where

$$
\left\langle Q_{\text {pot, net }}\right\rangle=\frac{1}{A} \int_{\text {Area }} Q_{\text {pot, net }} \mathrm{d} A,
$$

where $D$ is the duration of the summer and $A$ is the area of the observed surface.

It is possible that an important part of the ice cap is not visible during part of the year. This will lead to a misinterpretation of the mass balance. Therefore we used a curve to describe $\left\langle Q_{\text {pot, net }}\right\rangle$ with a priori knowledge about its course during the summer. A weight factor is introduced which gives the images with the least clouds the largest

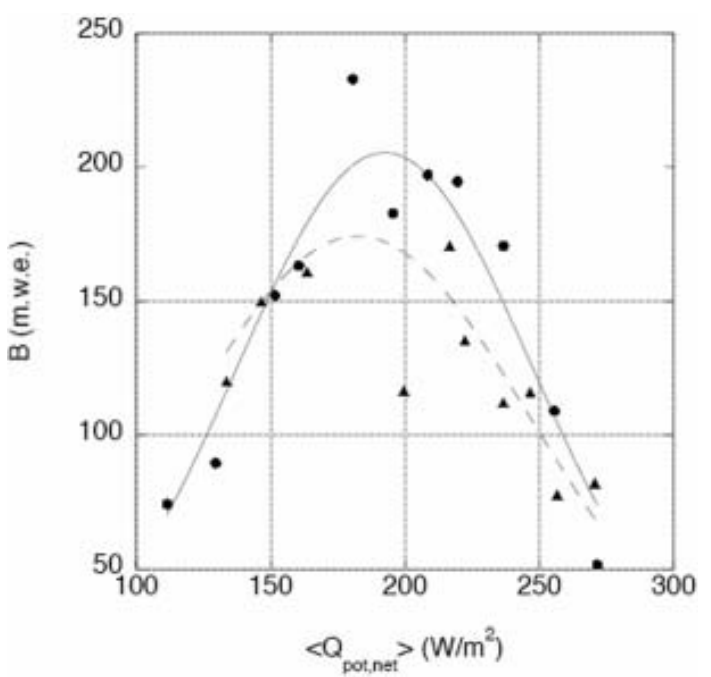

Fig. 2. Examples of the fit of Equation (3). This figure shows the most extreme years for Brúarjökull, namely 1993 (triangles and dashed line) and 1995 (circles and solid line).

weight. De Ruyter de Wildt and others (2002) found that the following Gaussian curve describes the changes in $\left\langle Q_{\text {pot, net }}\right\rangle$ well:

$$
\left\langle Q_{\text {pot, net }}\right\rangle=\operatorname{aexp}\left(-\frac{(\text { day }-b)^{2}}{c}\right),
$$

where $a, b$ and $c$ are tunable constants and day is the day of the year. Figure 2 shows $\left\langle Q_{\text {pot, net }}\right\rangle$ vs the day of the year for two extreme years on the drainage basin Brúarjökull. Every point in the graph depicts a single image. Before applying Equations (2) and (3) to estimate the mass balance, we describe the method to retrieve the surface albedo.

\section{SATELLITE IMAGE PROCESSING}

The AVHRR images were purchased from Dundee Satellite Receiving Station, Scotland. We attempted to acquire a cloud-free image every 2 weeks for April-October 19912003. However, it was not possible to obtain completely cloud-free images for every date, so a cloud-masking procedure was necessary. The images for the years 199194 were obtained from NOAA-11, those from 1995 to April 2001 were derived from NOAA-14, and all later images were acquired by NOAA-16 (Table 1). Bands 1 and 2 were used to determine the albedo of the surface, while bands 1 , 3 and 4 were used for cloud masking.

\section{Cloud masking}

It is often difficult to detect clouds over an ice cap, because clouds, ice and snow frequently have similar reflectance characteristics in the visible and infrared wavelengths. Thus, cloud masking becomes a matter of pattern recognition. De Ruyter De Wildt and others (2002) found that the differences between bands 3 and 4 could be used to aid in the detection of clouds. A parameter $R$ is defined as:

$$
R=\frac{\left|c_{4}-c_{3}\right|}{c_{4}+c_{3}}
$$

where $c_{3}$ and $c_{4}$ are the raw count values per pixel in the AVHRR bands 3 ( 3 a for NOAA-16) and 4 . If $R$ is higher than 
Table 1. Dates of the satellite images used in the analysis

Year Day/month

199115 Apr, 1 May, 25 May, 2 June, 17 June, 26 June, 7 July, 21 July, 8 Aug, 23 Aug, 6 Sept, 19 Sept

19926 May, 11 May, 28 May, 15 June, 18 June, 20 June, 3 July, 6 July, 14 July, 9 Aug, 10 Aug, 3 Sept, 11 Sept

199313 May, 26 May, 12 June, 18 July, 4 Aug, 10 Aug, 14 Aug, 3 Sept, 13 Sept, 27 Sept

199416 Apr, 29 Apr, 14 May, 15 June, 2 July, 8 July, 2 Aug, 12 Aug, 17 Aug, 30 Aug

199521 Apr, 9 May, 31 May, 9 June, 29 June, 14 July, 27 July, 7 Aug, 24 Aug, 12 Sept, 28 Sept

199627 Apr, 13 May, 19 June, 11 July, 27 July, 19 Aug, 25 Aug, 8 Sept, 20 Sept

199723 Apr, 20 May, 2 June, 26 June, 30 June, 17 July, 8 Sept, 18 Sept

19987 Mar, 2 Apr, 15 Apr, 4 May, 19 May, 10 June, 30 June, 14 July, 31 July, 8 Aug, 23 Aug, 4 Sept, 15 Sept, 29 Sept

19991 Apr, 21 Apr, 9 May, 28 May, 9 June, 29 June, 6 July, 21 July, 28 July, 5 Aug, 6 Aug, 18 Aug, 30 Aug, 20 Sept

200013 Apr, 2 May, 19 May, 24 May, 8 June, 23 June, 1 July, 8 July, 25 July, 6 Aug, 28 Aug, 5 Sept, 23 Sept, 30 Sept

200115 Apr, 3 May, 11 May, 23 May, 4 June, 9 June, 20 June, 13 July, 31 July, 9 Aug, 17 Aug, 8 Sept, 28 Sept, 4 Oct, 16 Oct

200210 Apr, 6 May, 17 May, 2 June, 27 June, 19 July, 30 July, 1 Aug, 14 Aug, 29 Aug, 2 Sept, 9 Sept, 28 Sept, 16 Oct

a chosen threshold, the pixel is classified as cloud. Threshold values are not equal for every image, and anomalies like cloud shadows are not detected. However, in addition to this procedure, we also examined a composite image of bands 1 (blue), 3 (red) and 4 (green). By including the visible band it was easier to see the extent of the ice cap and it was also possible to distinguish clouds from patterns in the ice itself and this enabled us to better tune $R$. Portions of the ice cap that were still suspect after the best possible $R$ had been chosen were removed manually.

\section{Geolocation}

We used a digital elevation model to produce a mask of the ice-cap margin. This mask was moved over the image until the fit with the margin was optimized. These fits were checked manually afterwards. We estimate that the accuracy of the geolocation is within one to two pixels.

\section{Calibration}

The raw count numbers of the AVHRR images in bands 1 and 2 were converted into top-of-the-atmosphere radiances. Rao and Chen (1995, 1999) and http://noaasis.noaa.gov/ NOAASIS/ml/n16calup.html provide calibration coefficients for bands 1 and 2 for the AVHRR instruments aboard NOAA11, NOAA-14 and NOAA-16 respectively. Instrumental drift is taken into account for NOAA-11 and NOAA-14, while the instruments aboard NOAA-16 have shown no systematic instrumental drift so far. However, the calibration coefficients have been updated several times, so the sensor is not completely stable. The zenith of the sun and the variable distance between the Earth and the Sun are also taken into account.

\section{Atmospheric correction and BRDFs}

The incoming radiation at the top of the atmosphere is not equal to the radiation received at the surface, because of the influence of the atmosphere. We used the 6S (Second Simulation of the Satellite Signal in the Solar Spectrum) model to determine this influence (Vermote and others, 1997). The model incorporates descriptions of both the anisotropic reflection of the atmosphere and the surface. The anisotropy of the latter is described using bidirectional reflection distribution functions (BRDFs). The BRDF for ice was derived by Greuell and de Ruyter de Wildt (1999) using measurements made on Morteratschgletscher, Switzerland, and the BRDF for snow was determined by Koks (2001) on the basis of measurements made on Glacier du Géant, Italy. We present the results with and without correction for anisotropy of the surface.

To distinguish between ice and snow we used the broadband albedo threshold of 0.43 determined by Greuell and others (2002). We selected this value because it was determined on Vatnajökull itself. If the broadband surface albedo after all corrections lay below 0.43 , the surface was classified as ice and otherwise as snow. If the images contradicted each other, i.e. the image with the snow BRDF classified the pixel as ice, while the ice BRDF image classified it as snow, the mean of the two broadband albedos was taken. With this method it is not a priori possible to say if a surface is ice or snow, because the broadband albedo is used to determine that. Therefore we had to calculate the albedo for all images with both BRDFs and select the correct surface type of each pixel afterwards.

The relation between the reflectance at the top of the atmosphere and the surface albedo depends on the suntarget-satellite geometry, water vapour, ozone and visibility. The latter is a measure for the aerosol content of the atmosphere. We generated a look-up table (LUT) that describes the relation between all possible zenith and azimuth angles of the sun and the satellite. The calculations were done for a standard sub-arctic summer profile with constant values for water vapour $\left(10.6 \mathrm{~kg} \mathrm{~m}^{-2}\right)$, total ozone (341 Dobson units) and visibility $(109 \mathrm{~km})$, all at 1500 ma.s.l.

To justify the use of constant values, we repeated all processing steps with atmospheric properties specific to each date for the years 2001 and 2002. Water vapour was taken from the ERA-40 re-analysis by the European Centre for Medium-Range Weather Forecasts, ozone content from NASA (http://www.toms.gfc.nasa.gov/ozone/ozone.html) and visibility from Fagurhólmsári station $\left(63^{\circ} 53^{\prime} \mathrm{N}\right.$, $16^{\circ} 39^{\prime} \mathrm{W}$ ) just south of Vatnajökull. This justified the use of the LUT values because the difference between the albedo calculated with both methods was only a few per cent at most.

\section{Slope correction}

All calculations above assume a horizontal surface, but this is seldom the case. We used the method of Knap and others (1999, equation 4) to correct for the slope of the surface. The 


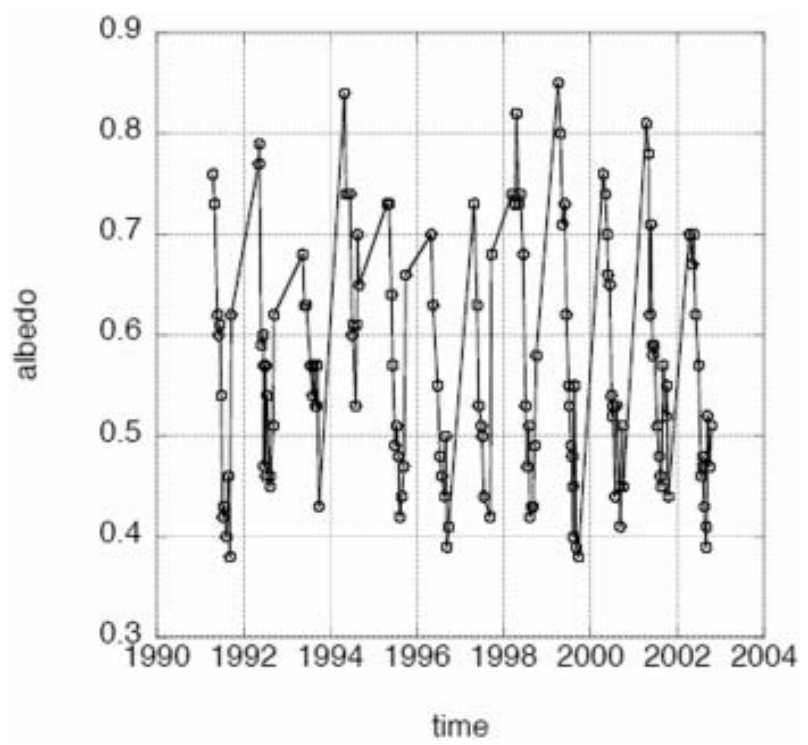

Fig. 3. Calculated albedo for the whole ice cap, 1991-2002. The standard run uses an isotropically reflecting surface and NTB conversion equation (6c). This figure clearly shows the interannual variability.

correction factor is defined as:

$$
F=\frac{\cos \theta_{\mathrm{s}}+\sigma}{\cos \gamma+\sigma}
$$

where $\theta_{\mathrm{s}}$ is the solar zenith angle, $\gamma$ is the angle between the normal vector of the surface and the vector pointing to the sun, and $\sigma$ is the ratio of diffuse to direct solar radiation under clear-sky conditions. Its value depends on the wavelength ( 0.138 and 0.079 for bands 1 and 2, respectively).

\section{Narrow-to-broadband conversion}

The calculations described above compute the narrowband albedos in AVHRR bands $1\left(\alpha_{1}\right)$ and $2\left(\alpha_{2}\right)$. These narrowband albedos have to be converted to a broadband albedo $(\alpha)$. We used several narrow-to-broadband (NTB) conversion equations and compared the results, namely:

de Ruyter de Wildt and others (2002):

$$
\alpha=0.5076 \alpha_{1}+0.0649 \alpha_{1}^{2}+0.2678 \alpha_{2}
$$

Greuell and others (2002):

$$
\alpha=0.632 \alpha_{1}^{2}+0.925 \alpha_{2}\left(1-\alpha_{2}\right)
$$

Greuell and Oerlemans (2004):

$$
\alpha=0.718 \alpha_{1}-0.137 \alpha_{1}^{2}+0.317 \alpha_{2}
$$

Liang (2001):

$$
\begin{aligned}
\alpha= & -0.3376 \alpha_{1}^{2}-0.2707 \alpha_{2}^{2}+0.7074 \alpha_{1} \alpha_{2} \\
& +0.2515 \alpha_{1}+0.5256 \alpha_{2}+0.0035
\end{aligned}
$$

\section{RESULTS}

This section is divided into two parts. The first deals with the uncertainties in the satellite-derived albedo, and the second deals with the mass balance determined using the calculated albedo. The results are presented in comparison with a standard run. This standard run uses an isotropically reflecting surface and NTB conversion equation (6c). Equation (6c) was chosen because it was the most recent NTB conversion equation available. The average albedo of

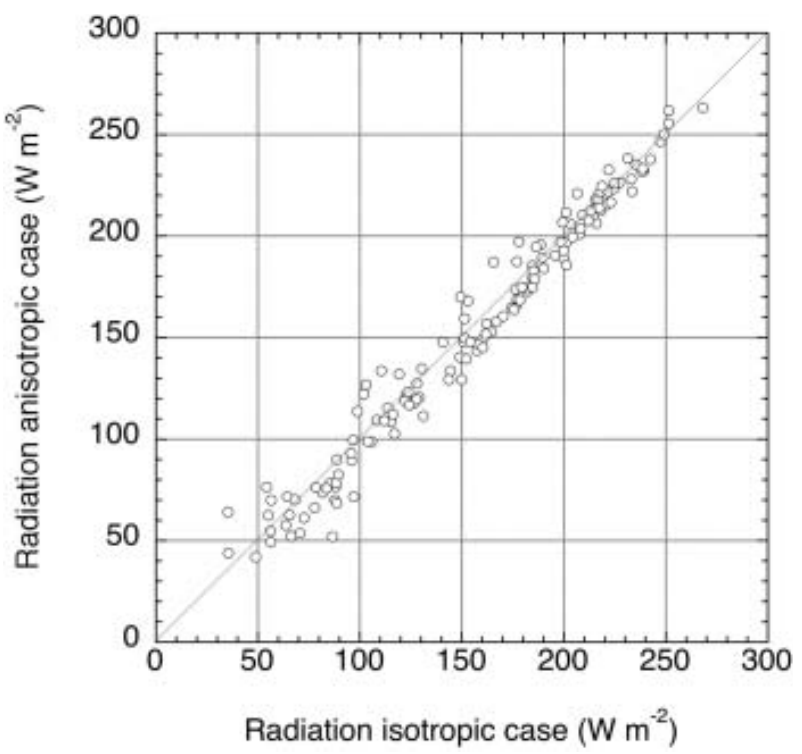

Fig. 4. Radiation calculated with an isotropically reflecting surface vs radiation calculated with an anisotropically reflecting surface. The correlation between the two cases is high $(R=0.985)$.

the whole ice cap is shown for the years 1991-2002 in Figure 3 for the standard run.

\section{Satellite-derived albedo}

The differences between the isotropic and anisotropic cases are typically on the order of a few per cent, as shown in Figure 4, and the correlation between both cases is large (0.98). The anisotropic albedo tends to be higher than the isotropic albedo, but there are exceptions. Not accounting for the anisotropy of snow and ice will, however, lead to errors in the calculated surface albedo. Knap and others (1999) did not correct for anisotropy and they considered this the main source of errors in their method. De Ruyter de Wildt and others (2002) corrected for snow, but not for ice, while Klok and others (2003) used BRDFs for both snow and ice. However, Greuell and Oerlemans (2004) argue that it is better to use no BRDF at all than one made for a glacier with completely different surface properties. Reijmer and others (2001) also mention that the BRDFs they derived for Antarctica cannot be used for other places. Albedo variations on Morteratschgletscher are mainly caused by the amount of water at the surface (Klok and others, 2003), while the dust content is more important for Vatnajökull (Greuell and others, 2002). Until these calculations are repeated with BRDFs specifically determined for Iceland, it is impossible for us to choose between the isotropic and the anisotropic case. Unfortunately, such BRDFs do not yet exist.

The NTB equations by Greuell and Oerlemans (2004) (Equation (6c)) and by Liang (2001) (Equation (6d)) are based on modelling and were subsequently compared with measurements, while Equations (6a) and (6b) are solely based on measurements. Equations (6c) and (6d) have been determined for a wide range of possible albedos. This is important, because extrapolation of NTB conversion equations beyond the range of albedos that were used as input for the equations is hazardous. However, by using different NTB equations we could estimate the effect of the NTB step on the calculated albedo. A scatter plot of the standard run albedo vs the other albedos is shown in Figure 5. Equation (6a) is a 


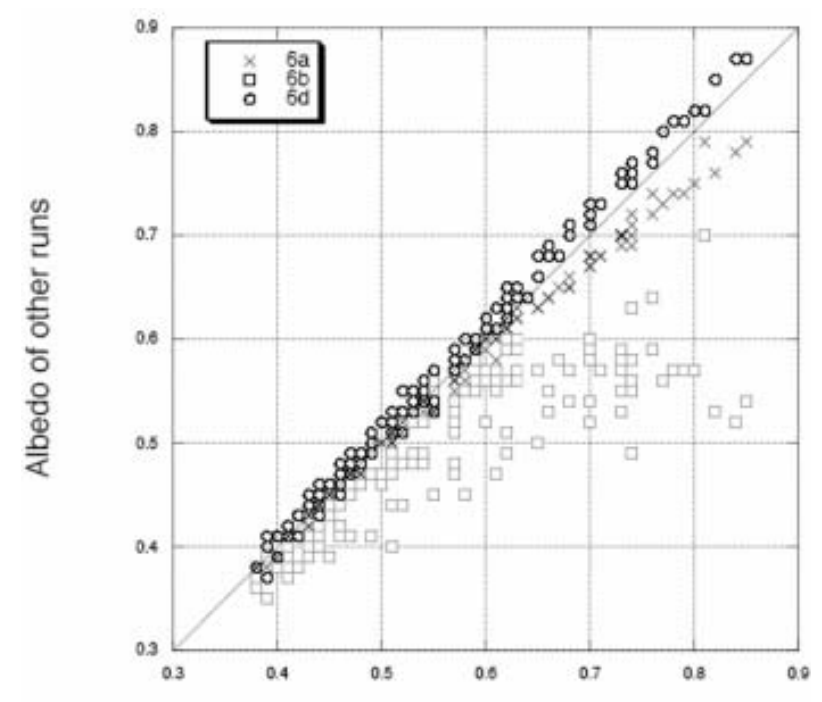

Albedo of standard run

Fig. 5. Albedo of the standard run (NTB conversion equation (6c)) vs albedo of the runs with NTB conversion equations (6a) (crosses), (6b) (squares) and (6d) (circles). The correlations are 0.996 for the (6a) run, 0.837 for the (6b) run and 0.997 for the (6d) run.

preliminary form of Equation (6b), so we expected that this version would perform worst. It was only included because it had been used in a previously published paper (de Ruyter de Wildt and others, 2002). However, the standard run albedo is more strongly correlated with Equations (6a) and (6d) than with (6b). Although Equation (6b) is more recent than (6a), it is based mostly on measurements of surfaces with low albedo. Indeed, the largest differences between the Equation (6b) and (6c) results are found among the higher albedos, with differences as large as $13 \%$. The correlation between $\left\langle Q_{\text {pot, net }}\right\rangle$ over the summer for these NTB conversion equations is strong in most cases (around 0.9). This comparison has shown that selection of a NTB conversion equation is no trivial matter, because it can lead to significant variations in the calculated albedo and also in $\left\langle Q_{\text {pot, net }}\right\rangle$, as shown in the next subsection.

\section{Mass balance determined by satellite compared with in situ measurements}

The mass balance was measured on the various drainage basins using a stratigraphic method. This method has been

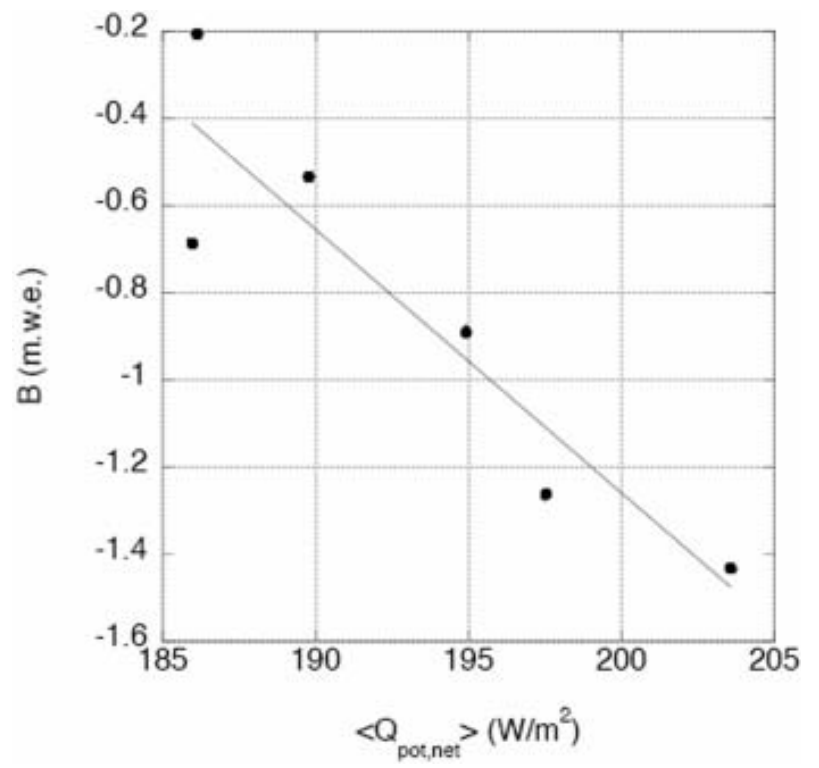

Fig. 6. Mean summer $\left\langle Q_{\text {pot,net }}\right\rangle$ for the standard run vs mean measured mass balance $(B)$ over the whole area where massbalance measurements were taken. The largest outlets were given the largest weight in the calculation of the mean. Every point shows a year, and only those years for which mass-balance measurements were available for all outlets are included.

described in detail in Björnsson and others (1998c). Briefly, it consists of measuring changes in thickness and density along a number of selected flowlines which span the elevation ranges of the drainage basins. The estimated error of the mass balance per outlet is $<20 \%$. The measured massbalance data were obtained from various reports from the Science Institute, University of Iceland (Björnsson and others, 1997, 1998a, b, c, 1999, 2002).

Figure 6 shows the potential absorbed radiation for the standard run vs the mass balance for several years for six drainage basins combined (Tungnaarjökull, Köldukvíslarjökull, Dyngjujökull, Brúarjökull, Breiðamerkurjökull and Eyjabakkajökull). The correlation between measured mass balance and $\left\langle Q_{\text {pot, net }}\right\rangle$ varies strongly between drainage basins (Table 2). Correlation coefficients are low if there are not enough mass-balance measurements and if not enough good images through the year are available. In particular, it was difficult to find good images at the beginning and at the end of the melt season, because clouds are more prevalent in

Table 2. Correlation coefficients $(r)$ and residual standard deviations (RSD) in m w.e. for measured mass balance vs mean summer $\left\langle Q_{\text {pot,net }}\right\rangle$ for six drainage basins of Vatnajökull. $B$ is the mean measured mass balance per outlet in $\mathrm{m}$ w.e. and $n$ is the number of years for which mass-balance measurements were available. (6a), (6b), (6c) and (6d) refer to the different NTB conversion equations discussed in the text

\begin{tabular}{|c|c|c|c|c|c|c|c|c|c|c|}
\hline \multirow[b]{3}{*}{ Outlet } & \multirow{3}{*}{$\begin{array}{c}b \\
\text { m w.e. }\end{array}$} & \multirow{3}{*}{$n$} & \multicolumn{2}{|c|}{ (6a) } & \multicolumn{2}{|c|}{ (6b) } & \multicolumn{2}{|c|}{$(6 c)$} & \multicolumn{2}{|c|}{$(6 d)$} \\
\hline & & & $r$ & RSD & $r$ & RSD & $r$ & RSD & $r$ & RSD \\
\hline & & & & mw.e. & & mw.e. & & mw.e. & & mw.e. \\
\hline Tungnaarjökull (T) & -1.085 & 8 & 0.79 & 0.413 & 0.44 & 0.550 & 0.75 & 0.478 & 0.75 & 0.405 \\
\hline Köldukvíslarjökull (K) & -0.660 & 9 & 0.53 & 0.305 & 0.00 & 0.290 & 0.40 & 0.329 & 0.29 & 0.278 \\
\hline Dyngjujökull (D) & -0.128 & 6 & 0.87 & 0.522 & 0.95 & 0.188 & 0.92 & 0.244 & 0.81 & 0.086 \\
\hline Bruarjökull (BU) & -0.217 & 10 & 0.86 & 0.010 & 0.89 & 0.128 & 0.93 & 0.073 & 0.90 & 0.227 \\
\hline Breiðamerkurjökull (BE) & -1.341 & 5 & 0.68 & 0.222 & 0.53 & 0.248 & 0.01 & 0.196 & 0.24 & 0.362 \\
\hline Eyjabakkajökull (E) & -1.240 & 7 & 0.67 & 0.003 & 0.77 & 0.008 & 0.65 & 0.013 & 0.60 & 0.033 \\
\hline
\end{tabular}


those periods. The residual standard deviation (m w.e.) is low in all cases (Table 2), showing that the data points are strongly related to each other even if the correlation is low. The choice of the NTB conversion equation has a large effect on the correlation coefficient and there is no single NTB conversion equation that performs best for all drainage basins (Table 2).

The correlations we determined are generally lower than those found by de Ruyter de Wildt and others (2002). The addition of the years 2000-02 is partly responsible for this, as 2001 and 2002 decrease the correlation substantially. The images from these years come from the NOAA-16 satellite, while all other images were acquired by NOAA-11 and NOAA-14. Köldukvìslarjökull gives by far the worst correlation coefficients for all three NTB equations, contrary to de Ruyter de Wildt and others (2002) who found a correlation of 0.92 . However, if the years 2001 and 2002 are removed, the correlation for the mean summer $\left\langle Q_{\text {pot, net }}\right\rangle$ and the measured mass balance becomes 0.83 for NTB conversion equation (6a) at Köldukvìslarjökull. Using data from different satellites may not be as straightforward as it seemed at first and this should be dealt with in future studies.

Assuming that the combination of the six drainage basins is representative of the whole ice cap both in space and time, we can estimate the total mass balance of the whole ice cap using the linear relation shown in Figure 6 . This is shown for the years 1991-2002 in Figure 7. We intend to validate this result in future work by comparing our findings with modelling studies and by adding more satellite images. The derived relation is unique for Vatnajökull, but this method can be applied to other ice masses which are large enough compared to the AVHRR pixel size; it has already been applied to part of Greenland by Greuell and Oerlemans (2005).

\section{CONCLUSIONS}

We tested a method to infer the mean surface mass balance of Vatnajökull from NOAA AVHRR satellite images for the years 1991-2002. The measured mass balance correlates well with mean summer $\left\langle Q_{\text {pot, net }}\right\rangle$ if enough cloud-free images can be found in an individual year and if the temporal variation in measured mass balances is high enough. The correlation between measured mass balance and mean summer $\left\langle Q_{\text {pot, net }}\right\rangle$ for all outlets combined was 0.92 , with a residual standard deviation of $0.18 \mathrm{~m}$ w.e.

The calculated albedo is greatly affected by the selected NTB conversion equation and, to a lesser extent, by the choice of BRDF. It is affected slightly by variations in atmospheric water vapour but not ozone or visibility, although these may be important for other ice masses. The correction for anisotropy of the surface is an important step in the satellite-image processing procedure, but until BRDFs are made for ice and snow in Iceland, this step will remain an important source of error.

Finally, switching between AVHRR instruments may cause a serious error in retrieved albedos. A recalibration like that presented by Greuell and Oerlemans (2005) may improve our results.

\section{ACKNOWLEDGEMENTS}

We thank M. de Ruyter de Wildt for his help with starting this project, A. Brooks and N. Lonie of Dundee Satellite

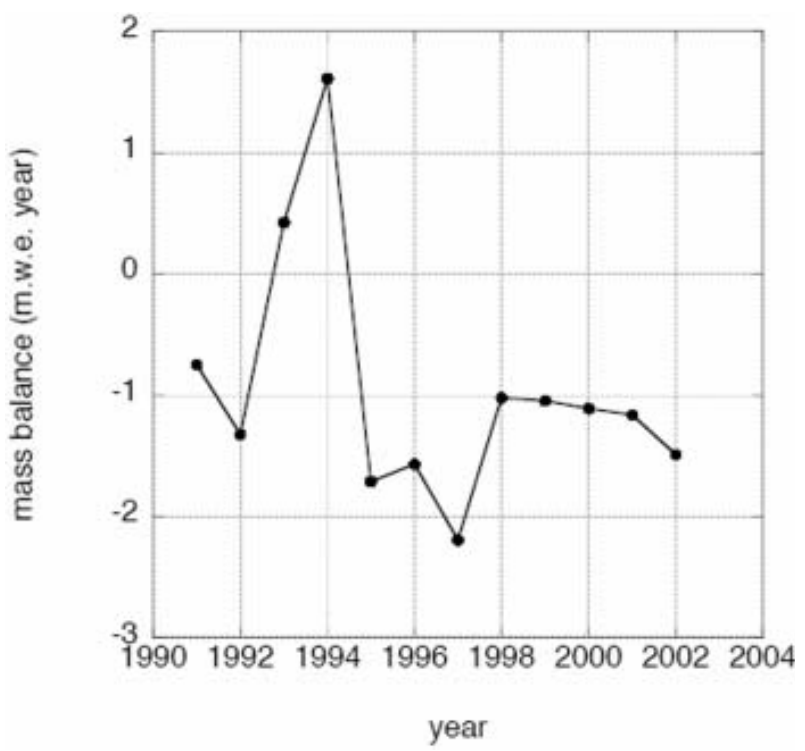

Fig. 7. Estimated mass balance for Vatnajökull based on the relation illustrated in Figure 6.

Station for providing the AVHRR images, G. Gísladóttir of the Icelandic Meteorological Office for the visibility data, and B. Brock and A. Klein for critical and helpful reviews. Our research was sponsored by SPICE (Space borne measurements of Arctic glaciers and implications for sea level), European Union grant EVK2-2001-00262 SPICE.

\section{REFERENCES}

Björnsson, H., F. Pálsson, M.T. Guðmundsson and H.H. Haraldsson. 1997. Afkoma, Hreyfing og afrennsli á vestan- og noráanveráum Vatnajökli jökuláriá 1995-1996. Reykjavík, Raunvísindastofnun Háskólans. (Report RH-24-97.)

Björnsson, H., F. Pálsson, M.T. Guðmundsson and H.H. Haraldsson. 1998a. Mass balance and meteorological observations on Vatnajökull 1997. Reykjavík, University of Iceland. Science Institute. (Report RH-03-98.)

Björnsson, H., F. Pálsson, M.T. Guðmundsson and H.H. Haraldsson. 1998b. Mass balance and meteorological observations on Vatnajökull 1998. Reykjavík, University of Iceland. Science Institute. (Report RH-14-98.)

Björnsson, H., F. Pálsson, M.T. Guð̀mundsson and H.H. Haraldsson. 1998c. Mass balance of western and northern Vatnajökull, Iceland, 1991-1995. Jökull, 45, 35-58.

Björnsson, H., F. Pálsson, M.T. Guð̀mundsson and H.H. Haraldsson. 1999. Mass balance and meteorological observations on Vatnajökull 1999. Reykjavík, University of Iceland. Science Institute. (Report RH-24-99.)

Björnsson, H., F. Pálsson and H. Haraldsson. 2002. Mass balance of Vatnajökull (1991-2001) and Langjökull (1996-2001), Iceland. Jökull, 51, 75-78.

De Ruyter de Wildt, M.S., J. Oerlemans and H. Björnsson. 2002. A method for monitoring glacier mass balance using satellite albedo measurements: application to Vatnajökull, Iceland. J. Glaciol., 48(161), 267-278.

De Ruyter de Wildt, M.S. and J. Oerlemans. 2003. Satellite-retrieval of mass balance: comparing SAR images with albedo images and in situ mass balance observations. J. Glaciol., 49(166), 437-448.

Greuell, W. and M.S. de Ruyter de Wildt. 1999. Anisotropic reflection by melting glacier ice: measurements and parameterizations in Landsat TM bands 2 and 4. Remote Sens. Environ., 70(3), 265-277. 
Greuell, W. and J. Oerlemans. 1986. Sensitivity studies with a mass balance model including temperature profile calculations inside the glacier. Z. Gletscherkd. Glazialgeol., 22(2), 101-124.

Greuell, W. and J. Oerlemans. 2004a. Narrowband-to-broadband albedo conversion for glacier ice and snow: equations based on modeling and ranges of validity of the equations. Remote Sens. Environ., 89(1), 95-105.

Greuell, W. and J. Oerlemans. 2004b. Validation of AVHRR- and MODIS-derived albedos of snow and ice surfaces by means of helicopter measurements. J. Glaciol., 51(172), 37-48.

Greuell, W. and J. Oerlemans. 2005. Assessment of the surface mass balance along the K-transect (Greenland ice sheet) from satellite-derived albedos. Ann. Glaciol., 42 (see paper in this volume).

Greuell, W., C.H. Reijmer and J. Oerlemans. 2002. Narrowbandto-broadband albedo conversion for glacier ice and snow based on aircraft and near-surface measurements. Remote Sens. Environ., 82(1), 48-64.

Hall, D.K., R.S. Williams, Jr, J.S. Barton, O. Sigurðsson, L.C. Smith and J.B. Garvin. 2000. Evaluation of remote-sensing techniques to measure decadal-scale changes of Hofsjökull ice cap, Iceland. J. Glaciol., 46(154), 375-388.

Klok, E.J., W. Greuell and J. Oerlemans. 2003. Temporal and spatial variation of the surface albedo of Morteratschgletscher, Switzerland, as derived from 12 Landsat images. J. Glaciol., 49(167), 491-502.

Knap, W.H., B.W. Brock, J. Oerlemans and I.C. Willis. 1999. Comparison of Landsat TM-derived and ground-based albedos of Haut Glacier d'Arolla, Switzerland. Int. J. Remote Sensing, 20(17), 3293-3310.

Koelemeijer, R., J. Oerlemans and S. Tjemkes. 1993. Surface reflectance of Hintereisferner, Austria, from Landsat 5 TM imagery. Ann. Glaciol., 17, 17-22.
Koks, M. 2001. Anisotropic reflection of radiation by melting snow. Landsat TM bands 2 and 4. (MSc thesis, Universiteit Utrecht.)

König, M., J.G. Winther and E. Isaksson. 2001. Measuring snow and glacier ice properties from satellite. Rev. Geophys., 39(1), 1-28.

Liang, S. 2001. Narrowband to broadband conversions of land surface albedo. I. Algorithms. Remote Sens. Environ., 76, 218-238.

Pelto, M.S. 2000. The impact of sampling density on glacier mass balance determination. Hydrol. Process., 14, 3215-3255.

Rao, C.R.N. and J. Chen. 1995. Inter-satellite calibration linkages for the visible and near-infrared channels of the Advanced Very High Resolution Radiometer on the NOAA-7, -9 and -11 spacecraft. Int. J. Remote Sensing, 16(11), 1931-1942.

Rao, C.R.N. and J. Chen. 1999. Revised post-launch calibration of the visible and near-infrared channels of the Advanced Very High Resolution Radiometer (AVHRR) on the NOAA-14 spacecraft. Int. J. Remote Sensing, 20(18), 3485-3491.

Reijmer, C.H., W.H. Knap and J. Oerlemans. 1999. The surface albedo of the Vatnajökull ice cap, Iceland: a comparison between satellite-derived and ground-based measurements. Bound.-Lay. Meteorol., 92(1), 125-144.

Reijmer, C.H., R. Bintanja and W. Greuell. 2001. Surface albedo measurements over snow and blue ice in thematic mapper bands 2 and 4 in Dronning Maud Land, Antarctica. J. Geophys. Res., 106(D9), 9661-9672.

Stroeve, J., A. Nolin and K. Steffen. 1997. Comparison of AVHRRderived and in situ surface albedo over the Greenland ice sheet. Remote Sens. Environ., 62(3), 262-276.

Vermote, E., D. Tanré, J.L. Deuzé, M. Herman and J.J. Morcette. 1997. Second simulation of the satellite signal in the solar spectrum: an overview. IEEE T. Geosci. Remote, 35(3), 675-686.

Walraven, R. 1978. Calculating the position of the Sun. Solar Energy, 20(5), 393-397. 